\title{
The Role of Control of Internal Business Receivables in Supporting the Effectiveness of Receiving Business Receivables (Case Study at PT X)
}

\section{Paulus Sugianto Yusuf* and Robertus Ary Novianto}

Widyatama University, Indonesia

*Paulus.sugianto@widyatama.ac.id

Article History: Received:11 January 2021; Accepted: 27 February 2021; Published online: 5 April 2021

\begin{abstract}
The research method used in this study is explanatory research. The population in this study was all employees at PT. X Home and Brach Office. Data collection techniques used in this study was using questionnaires with a total sample of 60 respondents. The program used in analyzing data uses SPSS Version 24. Based on the result of the study, it shows that Account Receivable Internal Control and Accounts Receivable Receipt Effectiveness is included in the good category. The result of the study also showed that account Receivable Internal Control in contributing to Accounts Receivable Receipt Effectiveness's 30.1\%. So the higher the Account Receivable Internal Control was, the Higher the Accounts Receivable Receipt Effectiveness.
\end{abstract}

Keywords: Internal control and effectiveness of receivables, internal control

\section{Introduction}

The business competition that is getting tighter in the current era of globalization is demanding companies to run their companies more effectively and efficiently. In achieving the effectiveness of a company, the company must achieve its goal, namely profit maximization. In maximizing profit, one way is to increase sales or revenue. An increase in revenue or sales can also increase accounts receivable. An uncontrolled increase in accounts receivable can result in bad debts.

At Detik Finance (2009), PT. Petrosea suffered a loss of US \$ 14.5 million due to a US \$ 26.9 million bleaching of uncollectible receivables, even though there was a decrease in expense accounts that succeeded in driving $44.99 \%$ of the first semester's gross profit to the US $\$ 24,895$ million from the US $\$ 17,170$ million. Likewise, administrative expenses were also successfully reduced by $15.67 \%$ to the US $\$ 8.392$ million in the first semester of 2009 from the previous US \$ 9,952 million. This boosted operating profit growth to reach $128.63 \%$ to the US $\$ 16.503$ million in the first semester of 2009. In the first semester of 2008, PTRO's operating profit was the US $\$ 7,218$ million.

Subaweh et al. (2008) states that the control of accounts receivable starts before the approval of sending merchandise, until after the preparation and issuance of invoices, and ends with the collection of the proceeds from the sale. Accounts receivable control procedures are closely related to cash receipts and inventory control.

\section{Literature Review}

\subsection{Previous related research}

Previous research consists of researches conducted by previous researchers related to this study. In addition, the research results of the related topic are presented in the table below:

\begin{tabular}{|c|c|c|c|}
\hline No. & Researcher & Research Title & Research Result \\
\hline 1. & $\begin{array}{lr}\text { Bagus } & \text { Nugroho } \\
\text { Susanto } & \text { and } \\
\text { Zulkarnain } & \text { MZ } \\
(2016) & \end{array}$ & $\begin{array}{l}\text { The Effect of Accounts } \\
\text { Receivable Control System and } \\
\text { Credit Sales Accounting on the } \\
\text { Effectiveness of Receivables } \\
\text { Collection at PT Usaha Lantang } \\
\text { Sejahtera Jakarta }\end{array}$ & $\begin{array}{l}\text { Accounts Receivable Control System and } \\
\text { Credit Sales Accounting have a positive } \\
\text { and significant effect on the effectiveness } \\
\text { of the collection of accounts receivable at } \\
\text { PT Usaha Lantang Sejahtera Jakarta }\end{array}$ \\
\hline 2. & Hery Sofyan (2008) & $\begin{array}{l}\text { Benefits of Accounts Receivable } \\
\text { Control System in Minimizing } \\
\text { Uncollectible Accounts }\end{array}$ & $\begin{array}{l}\text { The research results show that the Control } \\
\text { system is implemented quite effectively so } \\
\text { as to minimize uncollectible accounts that } \\
\text { appear in the company. }\end{array}$ \\
\hline 3. & Lestari (2019) & $\begin{array}{l}\text { The Role of Internal Control in } \\
\text { Supporting the Effectiveness of } \\
\text { Collecting Accounts Receivable }\end{array}$ & $\begin{array}{l}\text { Internal control plays a role in supporting } \\
\text { the effectiveness of collection of accounts } \\
\text { receivable. }\end{array}$ \\
\hline
\end{tabular}


The Role of Control of Internal Business Receivables in Supporting the Effectiveness of Receiving Business Receivables (Case Study at PT X)

\begin{tabular}{|c|c|c|}
\hline & $\begin{array}{lll}\text { at PT Central Bandung Raya } \\
\text { (Bandung city) }\end{array}$ & \\
\hline 4. $\quad$ Hardiyanti (2010) & 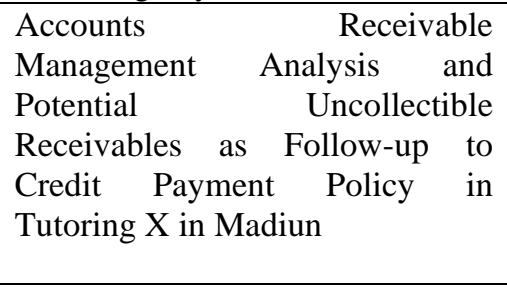 & $\begin{array}{l}\text { The management of receivables and the } \\
\text { potential doubtful at a tutoring agency } X \text { in } \\
\text { Madiun there have been improvements in } \\
\text { the new school year 2016-2017. So in the } \\
\text { new academic year 2015-2016 is no longer } \\
\text { doubtful, but still no payment policy on } \\
\text { credit to be paid each maturity. }\end{array}$ \\
\hline
\end{tabular}

\subsection{Accounts receivable internal control}

Internal control aspects of accounts receivable according to Firdaus A Dunia (2013) are as follows:

1 Separating the function of employees or the division that handles sales transactions (operations) from the accounting function for accounts receivable.

2 Employees in charge of accounting for accounts receivable must be separated from the function of receiving receivables.

3 All transactions for providing credit, giving deductions, and writing off receivables must be approved by the competent authority.

4 Receivables should be recorded in the accounts receivable supplementary books. The total of these supplementary book balances must be matched with the relevant ledger, at least once a month. In addition, at the end of the month customers (debtors) must be sent a statement of receivables.

5 The company must make a list of receivables based on their age.

According to Wilson and Campbell (2002), there are three general areas of control at which point action can be taken to bring about control of accounts receivable. The three fields are:

1. Granting trade credit.

2. Billing (Collections).

3. Determination and implementation of appropriate internal controls

\subsection{The effectiveness of acceptance of receivables}

According to Usman Sastradipraja 2010, accounts receivable turnover can be determined by dividing the amount of credit sales during a certain period by the average amount of accounts receivable. The formula used to measure the effectiveness of cash receipts from receivables is as follows:

Receivable Turn Over $=\frac{\text { Net Credit Sales }}{\text { Average Receivable }}$

Average receivable $=\frac{\text { Beginning Receivable }- \text { Ending Receivable }}{2}$

\subsection{Theoretical framework}

The results of his research prove that the accounting information system has a very important role in the implementation of the structure of accounts receivable internal control. This is one of the tools management in the company's operations. Hastoni and Dewi Susanti Aprilisabeth (2009) research prove accounting information systems 25 credit sales have a significant role to increase the effectiveness of internal control of receivables and cash receipts at PT Trinunggal Komara. This research is also in line with Noviani (2004), Hutapea (2011) and Ompusunggu (2002) in their research also proves that the accounting information system together affects the effectiveness of the implementation of internal control.

Based on this description, the following hypothesis can be formulated:

Ho: The Role of internal control influences effectiveness of acceptance of account receivable receives.

Ha: The role of internal control does not influence the effectiveness of acceptance account receivable 


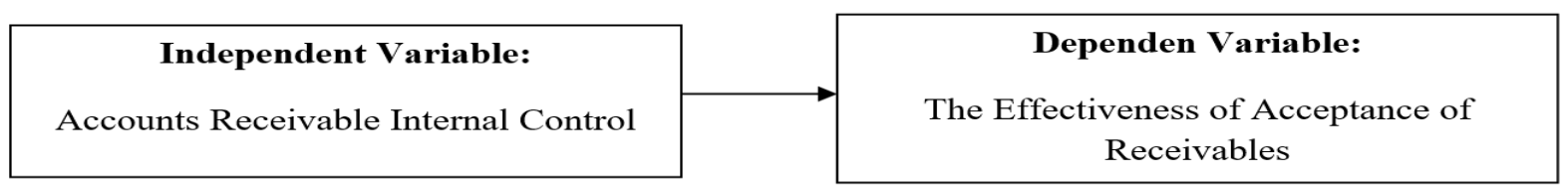

Figure 1. Theoretical framework

\section{Research Method}

Techniques for collecting data are through scientific texts, companies' financial statements; official websites download which are related to research variables.

\subsection{Classical assumption test}

This study uses the classical assumption assessment aimed at determining the accuracy of the relationship between variables (normally distributed or not) contained in the study. Types of classical assumption tests used are normality test (Kolmogrov Smirnov), Multicollinearity Test (VIF and Tolerance), heteroscedasticity test (Glejser), and autocorrelation test (run test) (Ghozali, 2018).

\subsection{Hypothesis testing}

This study uses the $t$ test that is testing the regression coefficient of each independent variable on the dependent variable to determine how much influence the independent variable has on the dependent variable. The criteria for making this hypothesis are taken as follows:

1) $H_{\mathrm{o}}$ rejected if $t$ statistic $<0,05$ or $t_{\text {calculated }}>t_{\text {table }}$;

2) $H_{o}$ accepted if t statistic $>0,05$ or $t_{\text {calculated }}<t_{\text {table }}$ (Ghozali, 2018)

\subsection{Independent variable illustration}

The independent variable is a stimulus for variables that affect other variables that are measured, manipulated or selected by the researcher to determine its relationship with an observed symptom (Jonathan Sarwono, 2006). In this study, there are independent variables (X) that is the role of internal control.

\subsection{Dependent variable illustration}

The dependent variable is the variable that responds when connected to the independent variable. The dependent variable is the variable whose variable is observed and measured to determine the effect caused by the independent variable (Jonathan Sarwono, 2006). In this study, the dependent variable (Y) is effectiveness acceptance account receivable.

\subsection{Operationalization of variables}

The following table shows the operationalization of the variables:

Table 1. Operationalization of variables

\begin{tabular}{|c|c|c|c|}
\hline Variable & Indicator & Sub Indicator & Scale \\
\hline \multirow{10}{*}{$\begin{array}{c}\text { The Role of Internal } \\
\text { Control (Variable X) } \\
\text { (Agoes, 2012; Romney, } \\
\text { 2015) }\end{array}$} & \multirow{7}{*}{ Control Environment } & Integrity and ethical value & \multirow{7}{*}{ Ordinal } \\
\hline & & Commitment to competence & \\
\hline & & $\begin{array}{l}\text { Participation of the board of } \\
\text { commissioners and audit } \\
\text { committee }\end{array}$ & \\
\hline & & $\begin{array}{l}\text { Management philosophy and } \\
\text { operating style }\end{array}$ & \\
\hline & & Organization Structure & \\
\hline & & Authority and Responsibility & \\
\hline & & $\begin{array}{l}\text { Human resource policies and } \\
\text { practices }\end{array}$ & \\
\hline & \multirow{3}{*}{ Risk Assessment } & Job Rotation & \multirow{3}{*}{ Ordinal } \\
\hline & & Clear Procedure & \\
\hline & & Transaction Responsibility & \\
\hline
\end{tabular}


The Role of Control of Internal Business Receivables in Supporting the Effectiveness of Receiving Business Receivables (Case Study at PT X)

\begin{tabular}{|c|c|c|c|}
\hline & & Seoreoation of duties & \\
\hline & & $\begin{array}{c}\text { Proper authorization of } \\
\text { transaction }\end{array}$ & \\
\hline & Control Activity & $\begin{array}{l}\text { Sufficient documents and } \\
\text { records }\end{array}$ & Ordinal \\
\hline & & $\begin{array}{l}\text { Physical control over assets and } \\
\text { records }\end{array}$ & \\
\hline & & $\begin{array}{c}\text { Internal verification or } \\
\text { inspection }\end{array}$ & \\
\hline & & Relevance & \\
\hline & Informtion ond Communiotion & Completeness & Ondinol 1 \\
\hline & Intormation and Communication & On time & Ordinal \\
\hline & & Clarity & \\
\hline & Monitoring & $\begin{array}{l}\text { Supervision of the accounts } \\
\text { receivable collection cycle }\end{array}$ & Ordinal \\
\hline & & Management supervision & \\
\hline & & $\begin{array}{l}\text { Well-formulated goals and } \\
\text { policies }\end{array}$ & \\
\hline & Terms-conditions for effective & $\begin{array}{l}\text { Classification and identification } \\
\text { of receivables appropriately }\end{array}$ & Ordinal \\
\hline & & Sufficient notes and reports & \\
\hline & & Sufficient working time & \\
\hline Effectiveness of & & A satisfying workforce & \\
\hline $\begin{array}{l}\text { Acceptance of Account } \\
\text { Receivable (Variable Y) }\end{array}$ & & $\begin{array}{l}\text { Preparation of a list of } \\
\text { receivables that are due }\end{array}$ & \\
\hline $\begin{array}{c}\text { (Indriyo \& Girosudarno, } \\
\text { 2002) }\end{array}$ & & $\begin{array}{l}\text { Billing goes directly to the } \\
\text { customer }\end{array}$ & \\
\hline & Billing Procedure & Submission of billing & Ordinal \\
\hline & B1lling Procedure & $\begin{array}{l}\text { Evaluate billing results and bill } \\
\text { lists }\end{array}$ & Ordinal \\
\hline & & $\begin{array}{c}\text { Submission of a list of invoices } \\
\text { to accounts receivable and } \\
\text { accounting }\end{array}$ & \\
\hline
\end{tabular}

\section{Results and Analysis}

The data obtained from the results of distributing questionnaires to several respondents will be used as a basis for providing responses regarding the Internal Control of Accounts Receivable which is measured using five indicators which are operationalized into 25 statement items. To find out the scores of respondents' answers related to each indicator of Internal Control Accounts Receivable at PT. X, then it is presented in tables.

Table 2. Recapitulation of respondents' responses about internal control variables accounts receivable (X)

\begin{tabular}{cccccc}
\hline No. & Indicator & Actual Score & Ideal Score & $\%$ & Criteria \\
\hline 1 & Control Environment & 2,151 & 2,400 & $89.63 \%$ & Good \\
\hline 2 & Risk Assessment & 806 & 900 & $89.56 \%$ & Good \\
\hline 3 & Control Activity & 2,153 & 2,400 & $89.71 \%$ & Good \\
\hline 4 & Information and Communication & 807 & 900 & $89.67 \%$ & Good \\
\hline 5 & Monitoring & 805 & 900 & $89.44 \%$ & Good \\
\hline & Total & 6,722 & 7,500 & $89.60 \%$ & Good \\
\hline
\end{tabular}

Table 3 shows that the average score of respondents 'answers to statement items regarding indicators on Internal Control of Accounts Receivable, the percentage of respondents' answers obtained is $89.6 \%$ when referring to the response rate, and then the value is included in the "Good" category. That is because the value is in the percentage between $" 76 \%-100 \%$.

The data obtained from the results of distributing questionnaires to a number of respondents will be used as a basis for providing responses regarding the Effectiveness of Receivables which are measured using two indicators which are operationalized into 18 statement items. To find out the scores of respondents' answers related to each indicator of the Effectiveness of Receivables from PT. X, then it is presented in tabular form. 
Table 3. Recapitulation of respondents' responses about the effectiveness of acceptance of accounts receivable (Y)

\begin{tabular}{cccccc}
\hline No. & Indicator & Actual Score & Ideal Score & $\%$ & Criteria \\
\hline 1 & Effective Receivables Collection Terms & 2,431 & 2,700 & $90.04 \%$ & Good \\
\hline 2 & Billing Procedure & 2,426 & 2,700 & $89.85 \%$ & Good \\
\hline \multicolumn{2}{c}{ Total } & 4,857 & 5,400 & $89.94 \%$ & Good \\
\hline
\end{tabular}

Table 3 shows that the average score of respondents 'answers to eighteen statement items regarding indicators on the Effectiveness of Accounts Receivable Receivables, the total percentage score of respondents' answers obtained is $89.94 \%$ when referring to the response rate, then the value is included in the category " Good "because the value is in the percentage between" $76 \%-100 \%$.

\subsection{Linear regression analysis}

Table 4. Multiple regression coefficient results Coefficients $^{\mathrm{a}}$

\begin{tabular}{ccccccc}
\hline & \multicolumn{2}{c}{ Unstandardized Coefficients } & \multicolumn{2}{c}{ Standardized Coefficients } \\
& Model & $\mathrm{B}$ & Std. Error & Beta & $\mathrm{t}$ & Sig. \\
\hline \multirow{2}{*}{1} & $($ Constant $)$ & 87.403 & 6.212 & & 14.070 & .000 \\
\cline { 2 - 7 } & $\mathrm{X}$ & .058 & .055 & -.136 & -1.042 & .302 \\
\hline
\end{tabular}

a. Dependent Variable: Effectiveness of Acceptance of Account Receivable Source: SPSS 22 Output Results

Based on the table above, it can be seen that the regression coefficient value is on the Unstandardized Coefficient " $\beta$ " value, so the regression equation can be presented as follows:

$$
\mathrm{Y}=87.403+0.058 \mathrm{X} 1
$$

The interpretation of the results of the regression equation for each of the above variables is as follows:

a. The constant value is 87.403 , which means that if all the independent variables, namely the role of internal control, have a value of 0 (zero) and there is no change, it is predicted that effectiveness of acceptance of account receivable will be worth $87.403 \%$.

b. The role of internal control value is 0.058 , which means that there is an increase of $0.058 \%$ in effectiveness of acceptance of account receivable when there is a one-unit increase in the role of internal control.

\subsection{Determination coefficient test $\left(\mathbf{R}^{2}\right)$}

Table 5. Coefficient of determination

Model Summary

\begin{tabular}{ccccc}
\hline Model & Model & R Square & Adjusted R Square & Std. Error of the Estimate \\
\hline 1 & 1 & .301 & .276 & 5.82503 \\
\hline
\end{tabular}

Predictors: (Constant), the role of internal control

Dependent Variable: effectiveness of acceptance of account receivable

Source: SPSS 22 Output Results

Based on the table above, the correlation coefficient value $\mathrm{X}$ with $\mathrm{Y}$ is obtained from the $\mathrm{R}$ value of 0.301 , so that it has a strong relationship. Meanwhile, the magnitude of the influence of $\mathrm{X}$ on $\mathrm{Y}$ is in accordance with the R Square value of 0.276 . So that the coefficient of determination of 0.276 shows that the role of internal control effect of $27.60 \%$ on effectiveness of acceptance of account receivable (Y). While the remaining $72.4 \%$ is influenced by other factors not observed in this study.

\subsection{Hypothesis test}

The role of internal control affects the effectiveness of acceptance of account receivable due to sig. the role of internal control is less than 0.05 and the $t_{\text {value }}$ of 14.070 is in the rejection area for Ho. 


\section{Discussion}

Internal control of trade accounts receivable to support the effectiveness of the collection of accounts receivable at PT $\mathrm{X}$ which is adequate as reflected in:

1. Overall there is a segregation of duties, namely a sales division and a billing division which is carried out by different people.

2. There is a culture of control in which supervisors are responsible for enhancing work ethics and high integrity and creating an organizational culture that supports and emphasizes to all employees of PT X the importance of internal controls that are being carried out.

3. There are monitoring activities and actions to correct deviations.

4. There are information and communication capable of facilitating the implementation of adequate operational activities.

5. The achievement of the objectives of internal control, namely compliance with applicable regulations, the availability of accurate and complete information, the effectiveness and efficiency of operational activities, and the effectiveness of the risk culture in the organization of PT. X thoroughly.

However, there are still several weaknesses in the internal control of trade accounts receivable in supporting the effectiveness of the collection of accounts receivable, including the following:

1. Current accounts are not routinely sent every month to customers that have been matched with credit cards by people who are not related to cash receipts, cash disbursements, and credit notes.

2. There are still heads of departments who do not supervise the divisions they head and there is still a lack of special training provided by management.

3. There are still some branches where the sales and billing departments are carried out by the same person so that collusion is still found.

4. Still not good at analyzing the feasibility of providing credit.

\section{Conclusion}

In general, the internal control for accounts receivable at PT $\mathrm{X}$ is very adequate and the effectiveness of acceptance of accounts receivable at PT X has been effective. The role of internal control was effect the effectiveness of acceptance of account receivable.

\section{References}

1. Azhar Susanto, (2013), Sistem Informasi Akuntansi, Struktur Pengendalian Resiko Pengembangan. Lingga Jaya, Bandung.

2. Bagus Nugroho Susanto and Zulkarnain MZ. 2016. Pengaruh Sistem Pengendalian Piutang dan Akuntansi Penjualan Kredit Terhadap Efektivitas Penagihan Piutang Pada PT Usaha Lantang Sejahtera Jakarta. Jurnal Akuntansi \& Bisnis Bisnis Krisnadwipayana, Vol 3, No 3.

3. Firdaus A.Dunia, 2013. Ikhtisar Lengkap Pengantar Akuntansi. Jakarta.

4. Ghozali, Imam. 2018. Aplikasi Analisis Multivariate dengan Program IBM SPSS 25. Badan Penerbit Universitas Diponegoro: Semarang.

5. Hastoni and Dewi Susanti Aprilisabeth. 2008. Peranan Sistem Informasi Akuntansi Penjualan Kredit dalam Meningkatkan Efektivitas Pengendalian Intern Piutang dan Penerimaan Kas. Jurnal Ilmiah Ranggading, Volume 8, No. 1, 30-36.

6. Hery Sofyan. 2008. "Manfaat Sistem Pengendalian piutang dalam Meminimalisasi Piutang Tak Tertagih. Skripsi, Universitas Widyatama.

7. Hutapea, Andry Aryanto. 2011. Pengaruh Penerapan Sistem informasi akuntansi penjualan kredit terhadap efektifitas pengendalian intern piutang. Abstrak. Skripsi S1 UNPAD.

8. Jonathan, Sarwono. 2006. Metode Penelitian Kuantitatif dan Kualitatif. Yogyakarta: Graha Ilmu.

9. Noviani 2004. Peranan Akuntansi Penjualan Dalam Menunjang Efektivitas Struktur Pengendalian Internal Penjualan Pada PT Jasa Marga (Persero) Cabang Padaleunyi Bandung. https://elib.unikom.ac.id/gdl.php?mod=browse\&op=read\&id=jbptunikompp-gdl-s1-2004-novianinim600 .

10. Nugraheni, P., \& Subaweh, I. (2011). Pengaruh Penerapan Standar Akuntansi Pemerintahan Terhadap Kualitas Laporan Keuangan. Jurnal Ilmiah Ekonomi Bisnis, 13(1).

11. Ompusunggu, H. (2002). Pengaruh Penerapan Sistem Informasi Akuntansi Terhadap Efektivitas Pelaksanaan Sistem Pengendalian Intern. Jurnal Akuntansi, 1(2), 1-10. 
12. R Lestari. 2019. Peranan Pengendalian Internal Dalam Menunjang Efektivitas Penagihan Piutang pada PT Central Bandung Raya (kota Bandung). Skripsi, Universitas Maranatha.

13. Novitasari, M., \& Hardiyanti, R. (2018). Analisis Pengelolaan Piutang Dan Potensi Piutang Yang Tidak Tertagih Sebagai Tindak Lanjut Kebijakan Pembayaran Kredit Pada Bimbingan Belajar X Di Madiun. Inventory: Jurnal Akuntansi, 1(2), 67-76.

14. Usman Sastradipraja. 2010. Analisis \& Penggunaan Laporan Keuangan (Modul Program Studi Akuntansi S1). Bandung: Universitas Widyatama.

15. Willson et al. 2002, Controllership, Jakarta: Erlangga.

16. https://finance.detik.com/bursa-dan-valas/d-1211822/putihkan-piutang-us-269-juta-petrosea-rugi-us145-juta?_ga=2.182870254.954697190.1521262663-464100835.1513388650. 